\title{
IMAGENS PARA NÃO DEIXAR DE VER O GESTO INUMANO
}

\section{IMAGES FOR NOT FAILING TO SEE THE INHUMAN GESTURE}

\author{
Guilherme Foscolo de Moura Gomes ${ }^{1}$ \\ Cynthia de Cássia Santos Barra²
}

RESUMO: Seguindo a pegada deixada por Didi-Huberman e colocando em destaque a questâo política da produçâo e reproduçâo das imagens, este ensaio pretende pensar as disputas tecnopolíticas por recurso a imagens. Nesse sentido, duas imagens específicas emergem no contexto das experiências transversais de formaçăo acadêmica nas universidades brasileiras, imagens que contam com a presença de mestres e mestras de tradiçôes orais como sujeitos capazes de legitimar modos outros de produçấo de saber e de fazer estético-políticas. A partir daí, coloca-se em movimento uma discussâo que compreende a materialidade dos aparatos tecnológicos (via Nietzsche, Marx e Kittler), a teoria geral dos gestos em Flusser, o conceito de dispositivo para Agamben e as relaçóes entre estética e política, segundo Benjamin e Rancière. Se parece evidente, de partida, que năo se passa - - que năo passaremos jamais - pelas tecnologias impunemente, o que (nos) resta como possibilidade de resistência e de potência de vida para o combate frente ao avanço aniquilador da falsa política? Pouco, talvez nada, talvez um quase nada, apenas, talvez, e ainda, imagens.

Palavras-chave: imagens; tecnopolíticas; dispositivos; gestos; mestres de oralidade.

ABSTRACT: Following the trail left by Didi-Huberman and bringing into the spotlight the political question of the production and reproduction of images, this essay reads technopolitical disputes by means of images. Hence, two specific images emerge in the context of transversal experiences of academic formation in Brazilian universities, images that rely on the presence of Masters of oral traditions as subjects capable of legitimizing other ways of producing aesthetic-political thought and making. From there, the essay discusses the materiality of the technological apparatuses (via

$1 \quad$ Coordenador do Grupo de Pesquisas Avançadas em Materialidades, Ambiências e Tecnologias (UFSB); integrante da Red Latinoamericana de Investigaciones em Prácticas y Medios de la Imagen, e Research Fellow do The Global Center for Advanced Studies. Host para o podcast/videocast Logotonia. Atualmente é professor na Universidade Federal do Sul da Bahia (UFSB).

2 Coordenadora do grupo de pesquisa Lêtera: estéticas, tecnologias, discursos (UFSB); integrante do Núcleo de Pesquisas Transdisciplinares Literaterras: escrita, leitura e traduçáo (UFMG) e do Grupo de Investigación Margenes: cartografías y discursos sobre la heterogeneidade, el canon y la marginalid (UNMSM/Peru). Coordenou o Mestrado Acadêmico em Estudos Literários da Universidade Federal de Rondônia/UNIR (2012-2014), onde desenvolveu o projeto de pesquisa intitulado "Livros da Floresta: do registro etnográfico à criaçăo literária" (Edital Universal CNPq/2012-2014). Atualmente é professora na Universidade Federal do Sul da Bahia (UFSB), onde coordenada o projeto interdisciplinar de pesquisa "Livro das Comunídades: o saber dos povos de tradiçăo oral e a inclusăo no ensino superior e na pesquisa no sul da Bahia". É ensaísta, com artigos e obras coletivas no campo das poéticas do livro. 
Nietzsche, Marx and Kittler), the general theory of gestures in Flusser, the concept of apparatus as developed by Agamben and the relations between aesthetics and politics, according to Benjamin and Rancière. If it seems obvious, at the outset, that we cannot relate to the technologies and remain unscathed, what remains as a possibility of resistance and life potency for the struggle against the annihilating march of false politics? Little, maybe nothing, maybe almost nothing, just, maybe, and still, images.

Keywords: images; technopolitics; apparatus; gestures; masters of oral tradition.

\title{
Ver/Devolver uma imagem
}

\author{
É imprescindível reparar. \\ Alargar a distância entre escrito e descrito. \\ À distância, torna-se-á evidente a natureza do trabalho estético. \\ E este, o que é, senão ver à sombra do que se nâo vê? \\ Há um náo vê que vela pelo vivo. Os seus efeitos sâo imprevisíveis, \\ é um facto, mas nâo duvido, \\ o que o texto tece advirá ao homem como destino. ${ }^{3}$
}

É Didi-Huberman quem, em um ensaio intitulado "Devolver uma imagem", coloca em movimento a "questăo totalmente tola [...] e totalmente maldosa" que se abre diante da expressăo "tirar uma foto": ao perguntar-se, a respeito da expressăo, "mas o que se tira, a quem se tira exatamente?", Didi-Huberman pōe a descoberto a questăo política da produçâo e reproduçāo das imagens (DIDI-HUBERMAN, 2015, p. 205).

$\mathrm{Na}$ era da reprodutibilidade técnica, os aparatos tecnológicos refinam o processo de isolamento e atomizaçăo do humano. As informaçôes, embora circulem, nâo habitam mais o espaço público: sâo produzidas e reproduzidas em espaços privados. Mesmo a televisăo, responsável pelo processo de atomizaçâo que confinou as famílias às salas das próprias residências, foi substituída pela tela digital, o que tornou a "sala de televisăo" - ela mesma, em princípio, um subproduto do aparato - um espaço obsoleto.4 Em uma mesma residência, os habitantes dispóem de telas pessoais distintas (dos computadores aos tablets ou celulares); năo é um fenômeno incomum, aliás, que as pessoas dividam a mesma cama, mas năo dividam a mesma tela. A Netflix, empresa que fabrica e vende imagens de tela privada em tela privada, oferta planos família, ajustáveis às subjetividades que promete acomodar. Nâo por acaso, muito recentemente, a organizaçăo de Cannes entrou em polêmica com a Netflix, restringindo a participaçáo no festival - para o ano de 2018 - aos filmes que estrearam em salas de cinema.5

3 LLANSOL, Maria Gabriela. O Senhor de Herbais: breves ensaios literários sobre a reproduçáo estética do mundo, e suas tentaçōes. Lisboa: Relógio D`água, 2002, p. 210.

4 Cf.: ARRAES, Marcos Alexandre de Melo Santiago. Tramas do Olhar: americanismo, Guerra Fria e a emergência de um novo regime visual no Brasil entre 1945-1964. 2015. 230f. Tese (Doutorado em História pela Universidade Federal de Santa Catarina), Universidade Federal de Santa Catarina, Florianópolis, 2015; particularmente o subcapítulo 3.2. Sob os auspícios do T(er) V(er): a vida enquadrada em uma tela". Disponível em: <https://repositorio.ufsc.br/bitstream/handle/123456789/160760/337714. pdf? sequence=1>. Acesso em: 01 jun. 2017.

5 Cf.: EL PAÍS. Editorial. Cannes Contra Netflix. 21 maio 2017. Disponível em: <http://brasil.elpais.com/ brasil/2017/05/21/opinion/1495382482_349481.html>. Acesso em: 01 jun. 2017. 
Nos parece claro, e a isso retornaremos mais adiante, que quanto mais atomizador o aparato mais ele opera na contramáo da produçăo de subjetividades: mais ele opera, portanto, como aparato dessubjetivador.

O efeito rebote de todo esse processo, lembra-nos Didi-Huberman (à moda de Guy Debord, Jean Baudrillard et al.), é a sensaçăo de que "nada se passa no mundo se nâo se passar na televisăo" (DIDI-HUBERMAN, 2015, p. 206). Mas, avança Didi-Huberman, "é possível devolver algo à esfera pública para além dos limites do aparato". Justificase aí o recurso às obras de Harun Farocki - pois que ele "nos mostra, em seus filmes ou instalaçôes, conjuntos de imagens que năo tinham, de início, vocaçâo para serem tornadas públicas" (DIDI-HUBERMAN, op. cit., p. 207). Farocki devolve à esfera pública justamente aquilo que o aparato dela oculta (imagens operadoras dos aparatos que produzem - imagens). Ou, como coloca Didi-Huberman (op. cit., p. 206):

É preciso instituir os restos: tomar nas instituiçōes o que elas nâo querem mostrar - o rebotalho, o refugo, as imagens esquecidas ou censuradas - para retorná-las a quem de direito, quer dizer, ao "público", à comunidade, aos cidadâos.

O que Farocki faz é restituir a materialidade dos aparatos. Em última instância, Farocki faz ver uma medialidade através de sua programaçâo (isto é, dos seus efeitos sobre nossos corpos). O que o texto tece advirá ao homem como destino: nossos aparatos se inscrevem em nossos corpos. Neste ensaio, tomaremos a Literatura numa perspectiva expandida, na qual desejamos que incida o pensamento imagético e o conceitual. Será nossa tentativa de ver à sombra do que nâo se vê: de devolver - como o faz o Farocki de Didi-Huberman - imagens que façam ver o rebotalho, o refugo, a materialidade dos media.

Desde 2006, temos acompanhado, em espaços acadêmicos (a princípio na UFMG e na UNB; e agora na UFSB), experiências designadas como Formaçôes Transversais e/ou Encontro de Saberes. Nessas experiências, de caráter formativo, com objetivo político de refundar as universidades brasileiras com um logos de-colonialista, encontramo-nos presencialmente com mestras e mestres de saberes populares, de matrizes indígenas e/ou africanas: sâo quilombolas, raizeiros e raizeiras, artífices, construtores, barqueiros, brincantes do Cavalo Marinho, congadeiros e congadeiras, mestres e mestras de Coco, das Folias, Catira e Lundu, mestras e mestres xamă, Ogăs e Yalorixás, Mametos, Tatas e Makotas. Essa série de encontros (fora de uma lógica categorial das séries, com modos de subjetivaçăo específicos) tornam-se, muitas vezes, acontecimentos eminentemente estéticos: performances e narrativas que produzem e/ou atualizam, por tais vias, imagens pertinentes às culturas e às artes existentes no Brasil.

Na universidade, essas imagens, que fazem emergir mundos no mundo e, no limite, parecem desejar o impossível - colocar em suspensâo a era da reprodutibilidade técnica, tudo ali sendo tăo singular como só sabem ser os acontecimentos -, tem que se ver com o risco crescente (e sempre presente) de serem tiradas e nâo devolvidas, e isso em razâo do próprio processo tecnológico da qual depende a sua traduçâo institucional. Quem e em quais lugares/circunstâncias pode fazer ver/desver é, afinal, também resultado de uma disputa tecnopolítica. Tomemos, pois, essas imagens - especificamente duas delas com as quais estivemos envoltos de maneira mais próxima - no campo 
específico do saber literário e das discussōes político-estéticas contemporâneas; e vejamos aonde nos leva a escrita desses (des)encontros.

\section{Técnicas e aparatos [contemporâneos] para ver/devolver imagens [ancestrais]}

Imagem 1. Em um de nossos primeiros encontros, ${ }^{6}$ o Tata Kambondo Marinho Rodrigues iniciou sua fala com um agradecimento pelo convite para falar na UFSB no contexto do projeto Encontro de Saberes, que para ele representava um reconhecimento, uma valorizaçăo de seus saberes tradicionais. Saberes que, muitas vezes, ele explica, a universidade desconhece. Marinho, que se considera um aprendiz em contato com mestres, falou do tempo de seu aprendizado com seus mestres, aprendizado que depende de um tempo. Năo se trata, é preciso esclarecer desde já, do tempo do trabalho no e para o Capital, mas de um tempo de outra ordem, e que movimenta outras formas de ser/existir. Na sequência de seu agradecimento, Marinho Rodrigues canta uma zuela para pedir licença. Depois do canto, do ritual, Marinho explica que quebrará protocolos: embora tenha feito slides, um texto-guia e anotaçōes etc. sua formaçăo (diz ele próprio) é muito diferente daquilo tudo que havia preparado. 0 gesto de cantar a zuela parece reivindicar outra fala, distinta da que se movimenta na universidade. Reivindica, para colocarmos de forma mais precisa, outro modo de pensar: daí porque Marinho abandona suas anotaçóes para fazer uma fala como sabe, como aprendeu em sua naçấo angola-congo, com seus tambores sagrados. O gesto de Marinho é duplamente revelador. Revela, por um lado, a relaçáo que se estabelece entre percepçáo humana, comunicaçấo e dispositivos tecnológicos. Por outro lado, permite-nos ver o espaço da universidade pública como um dos últimos redutos do pensamento-pela-escrita, ou do pensamento que se materializa pela escrita. ${ }^{7}$

Ressalto 1. É Vilém Flusser quem aponta, em Gesten, para a possibilidade de se pensar numa "teoria geral dos gestos". A reflexăo de Flusser na direçâo de uma teoria dos gestos faz do (des)encontro entre pensamentos que expressam tecnologias distintas algo mais do que uma mera sutileza - de fato, faz desta primeira imagem (Marinho canta a zuela) uma ruptura (e da segunda imagem, como veremos, até mesmo uma violência). Flusser define o gesto como "um movimento do corpo ou de uma ferramenta

O projeto "Escolas de Tambores: aparatos e técnicas contemporâneas para ver/devolver imagens ancestrais" é o plano piloto de um programa de pesquisa-intervençăo no qual atuam o Grupo de Pesquisas Avançadas em Materialidades, Ambiências e Tecnologias (UFSB/CNPq), o núcleo Lêtera: estéticas, tecnologias, discursos (UFSB/CNPq), a Escola de Percussāo e Dança Afro-brasileira e a Organizaçâo Gongombira, da Rede Matamba Tombenci Neto (Ilhéus/BA). Todos os registros audiovisuais referidos por nós, por meio dos quais nos foi possível descrever/escrever as imagens 1 e 2 , pertencem ao acervo deste projeto.

$7 \quad$ All that is about to change. The official thinking of an increasingly significant elite expresses itself in the programming of cybernetic data banks and computational facilities that are structured differently from the gesture of writing. The masses are programmed with the codes of technical images and, in this sense, are becoming illiterate again. (A systems analyst does not need to write, the computer functions without the alphabet, and mass culture does not require reading. The television does not need letters to be informative.) The gesture of writing is about to become an archaic gesture, expressing a way of being that has been overtaken by technical developments. FLUSSER, Vilém. Gestures. Traduçâo: Nancy Ann Roth. Minneapolis/London: University of Minnesota, 2014, p. 25. 
anexada ao corpo para o qual năo há uma explicaçăo causal satisfatória" (FLUSSER, 2014, p. 3). ${ }^{8}$ Náo há explicação causal satisfatória porque gestos săo formalizaçōes de afetos, e afetos sâo estados mentais transformados em gestos. "O afeto", diz Flusser, "libera estados mentais de seus contextos originais e permite que eles se tornem formais (estéticos) - assumindo a forma de gestos" (op. cit., p. 6). ${ }^{9}$ O pensamento, portanto, "se expressa em uma vasta gama de gestos" (op. cit., p. 24). ${ }^{10}$ Mas há aí um catch:

Năo há pensamento que nâo tenha sido articulado através de um gesto. 0 pensamento antes de ser articulado é apenas uma virtualidade, ou seja, nada. Ele é realizado através do gesto. Estritamente falando, năo há pensamento antes de se fazer o gesto. (FLUSSER, 2014, p. 24) ${ }^{11}$

Isto é: há que se considerar o gesto mais do que como a representaçâo/materializaçăo do pensamento, pois que o gesto é o pensamento ele mesmo, em sua instância de produçáo - a matéria. Media distintos, portanto, náo representam pensamentos, mas sâo modos de pensar distintos. Náo ser capaz de expressar as ideias, para Flusser, dá no mesmo que ser incapaz de pensar. ${ }^{12}$

"Năo é certo dizer que a escrita corrige o pensamento. A escrita é um modo de pensar" (FLUSSER, 2014, p. 24). ${ }^{13}$ Mas năo qualquer modo de pensar. A escrita, para Flusser, é o "pensamento oficial do Ocidente" (FLUSSER, 2014, p. 24). ${ }^{14}$ Quando Marinho abandona as suas anotaçóes para cantar uma zuela - Marinho póe em suspensáo a hegemonia escrita, o pensamento oficial do Ocidente, para pensar musicalmente. Pensar musicalmente é, por óbvio, pensar por outros aparatos! Năo é como se Marinho năo conseguisse se expressar bem pela via da escrita, e tivesse que fazer recurso a outro aparato. Mas é que pensar musicalmente é reconhecer o pensamento que a música movimenta. Reconhecer que a música é pensamento. Mais precisamente poderíamos dizer que Marinho pensa ali como um percussionista. Mas nâo como um qualquer percussionista: como Tata Kambondo que é, mestre/aprendiz de $\mathrm{Ngoma}^{15}$ - com sua escola de tambores, adentrando o espaço universitário e tentando encontrar (instaurar) aí lugares e modos de subjetivaçăo e de agenciamentos coletivos.

Ressalto 2. Mas o que é um aparato/instrumento/dispositivo? Em “O que é um dispositivo", Agamben assim o define:

8 One way of defining 'gesture' is as a movement of the body or of a tool attached to with the body, for which there is no satisfactory causal explanation. FLUSSER, op. cit., p. 3.

9 Affect releases states of mind from their original contexts and allows them to become formal (aesthetic) - to take the form of gestures. FLUSSER, op. cit., p. 6.

10 Thinking expresses itself in a whole range of gestures. FLUSSER, op.cit., p. 24.

11 There is no thinking that has not been articulated through a gesture. Thinking before articulation is only a virtuality, which is to say, nothing. It is realized through the gesture. Strictly speaking, there is no thinking before making the gesture. FLUSSER, op. cit. p. 24.

12 Someone who says that he is unable to express his ideas is saying that he is not thinking. FLUSSER, op. cit. p. 24.

13 It is not right to say that writing fixes thinking. Writing is a way of thinking. FLUSSER, op. cit., p. 24.

14 Writing is the 'official thinking' of the West. FLUSSER, op. cit., p. 24.

15 Ngoma, tambor em banto. No Brasil, Ngoma é um artefato usado em cerimônias de Candomblé Angola. 
Generalizando posteriormente a já amplíssima classe dos dispositivos foucaultianos, chamarei literalmente de dispositivos qualquer coisa que tenha de algum modo a capacidade de capturar, orientar, determinar, interceptar, modelar, controlar e assegurar os gestos, as condutas, as opiniôes e os discursos dos seres viventes. Náo somente, portanto, as prisōes, os manicômios, o panóptico, as escolas, as confissóes, as fábricas, as disciplinas, as medidas jurídicas etc., cuja conexăo com o poder é em um certo sentido evidente, mas também a caneta, a escritura, a literatura, a filosofia, a agricultura, o cigarro, a navegaçăo, os computadores, os telefones celulares e por que năo - a linguagem mesma, que é talvez o mais antigo dos dispositivos, em que há milhares e milhares de anos um primata - provavelmente sem dar-se conta das consequências que se seguiriam - teve a inconsciência de se deixar capturar. (AGAMBEN, 2005, p. 13)

Dispositivos, portanto, sâo também definidos como quaisquer tecnologias capazes de "capturar, orientar, determinar, interceptar, modelar, controlar e assegurar os gestos". Por óbvio, já deixamos aqui há muito para trás o horizonte que pensa os dispositivos como instrumentos passivos da comunicaçăo. A afirmaçáo da dimensáo material dos processos de comunicaçăo data do século XIX, e sua nada intempestiva constataçăo pode ser verificada em autores (em quase tudo o mais tăo distantes) como Marx e Nietzsche. No posfácio para a segunda ediçāo de O Capital, dirá Marx:

Meu método dialético, em seus fundamentos, năo é apenas diferente do método hegeliano, mas exatamente o seu oposto. Para Hegel, o processo de pensamento, que ele, sob o nome de Ideia, chega mesmo a transformar num sujeito autônomo, é o demiurgo do processo efetivo, o qual constitui apenas a manifestaçáo externa do primeiro. Para mim, ao contrário, o ideal náo é mais do que o material, transposto e traduzido na cabeça do homem. (MARX, 2013, p. 90)

É a percepçăo desta dimensăo material, de quem já pensa os media como dispositivos năo somente tecnológicos, mas também sócio históricos, que possibilita a Marx se perguntar, nos Grundrisse, se "é possível Aquiles com a pólvora e chumbo? Ou mesmo a Ilíada com a imprensa ou, mais ainda, com a máquina de imprimir? Com a alavanca da prensa, nâo desaparecem necessariamente a cançâo, as lendas e a musa, năo desaparecem, portanto, as condiçôes necessárias da poesia épica?" (MARX, 2011, pp. 91-92). O segundo capítulo de $O$ Capital năo deixa restar dúvidas sobre a determinaçăo que tais dispositivos impóem sobre nossos corpos, ainda que Marx esteja a falar, é claro, da mercadoria:

As mercadorias năo podem ir por si mesmas ao mercado e trocar-se umas pelas outras. Temos, portanto, de nos voltar para seus guardiôes, os possuidores de mercadorias. [...] Aqui, as pessoas existem umas para as outras apenas como representantes da mercadoria e, por conseguinte, como possuidoras de mercadorias. Na sequência de nossa exposiçăo, veremos que as máscaras econômicas das pessoas náo passam de personificaçôes das relaçóes econômicas, e que as pessoas se defrontam umas com as outras como suportes [Träger] dessas relaçōes. (MARX, 2013, p. 160)

A inversâo marxiana é contra intuitiva, e faz dos corpos veículos de expressâo do dispositivo. A famosa frase que abre $O$ Capital poderia, a propósito, muito bem ser lida do seguinte modo: nas sociedades onde reina o modo de produçăo capitalista, o que 
os corpos exprimem (o que os corpos de fato se tornam) é a língua das mercadorias. ${ }^{16}$ Nesse sentido o depoimento de um Nieztsche é ainda mais revelador. Em 1882, de posse da máquina de escrever de Malling-Hansen, Nietzsche registra em carta datilografada que "nossas ferramentas de escrita também trabalham o nosso pensamento". ${ }^{17}$ Para Kittler, Nietzsche é o primeiro filósofo-mecanizado, o primeiro a anunciar (denunciar?) a interferência das tecnologias no humano. Após sua experiência com a máquina, dirá Kittler, "Nietzsche [...] mudou de argumentos para aforismos, de pensamentos para trocadilhos, de retórica para o estilo de telegrama. Isso é precisamente o que se quer dizer pela sentença 'nossas ferramentas de escrita também trabalham o nosso pensamento"' (KITTLER, 1999, p. 201). ${ }^{18}$

A máquina, como se sabe, é adquirida por Nietzsche em $1881 .{ }^{19}$ Em 1887 Nietzsche publica a Genealogia da Moral, e eleva a máquina de escrever (a de Malling Hansen) "ao status de uma filosofia":20

E esta filosofia, ao invés de derivar a evoluçâo do ser humano do espírito de Hegel (nas entrelinhas dos livros) ou do trabalho de Marx (entre o potencial diferencial da energia muscular), começou com uma máquina de informaçăo. No segundo ensaio de Genealogia da Moral, o conhecimento, o discurso e a açăo virtuosa náo sâo mais atributos inatos do Homem. Como o animal que em breve receberá um nome distinto, o Homem derivou do esquecimento e do barulho aleatório, pano de fundo de toda a mídia. 21 (KITTLER, 1999, p. 210)

O segundo ensaio da Genealogia dá testemunho de uma filosofia que pensa os humanos como máquinas em que se inscrevem memórias. "Como fazer no bicho-homem uma memória", pergunta Nietzsche. "Como gravar algo indelével nessa inteligência voltada para o instante, meio obtusa, meio leviana, nessa encarnaçáo do esquecimento?" (NIETZCHE, 1998, GM II:3). De agentes à superfície programável ("os humanos

16 "A riqueza das sociedades onde reina o modo de produçâo capitalista aparece [erscheint] como uma 'enorme coleçáo de mercadorias', e a mercadoria individual, por sua vez, aparece como sua forma elementar". MARX, Karl. O Capital: crítica da economia política. Traduçâo: Rubens Enderle. Sáo Paulo: Boitempo, 2013. Livro I: o processo de produçâo do capital. p. 113. A propósito da "língua das mercadorias": "Como se vê, tudo o que a análise do valor das mercadorias nos disse anteriormente é dito pelo próprio linho assim que entra em contato com outra mercadoria, o casaco. A única diferença é que ele revela seus pensamentos na língua que lhe é própria, a língua das mercadorias". MARX, op. cit., p. 129.

17 "Unser Schreibzeug arbeitet mit an unseren Gedanken", como citado por Friedrich Kittler: KITTLER, Friedrich. Gramophone, Film, Typewriter. Traduçăo e introduçăo: Geoffrey Winthrop-Young; Michael Wutz. Stanford: Stanford University, 1999. p. 200.

18 "Indeed: Nietzsche, as proud of the publication of his mechanization as any philosopher, 81 changed from arguments to aphorisms, from thoughts to puns, from rhetoric to telegram style. That is precisely what is meant by the sentence that our writing tools are also working on our thoughts. Malling Hansen's writing ball, with its operating difficulties, made Nietzsche into a laconic". KITTLER, op cit., p. 203.

19 Nietzsche planeja adquiri-la pelo menos desde 1879, na expectativa de contornar as dores nos olhos e o espectro da cegueira. Cf.: KITTLER, op. cit., p. 201.

20 Id., p. 210.

21 "And this philosophy, instead of deriving the evolution of the human being from Hegel's spirit (in between the lines of books) or Marx's labor (in between the differential potential of muscular energy), began with an information machine. In the second essay of On the Genealogy of Morals, knowledge, speech, and virtuous action are no longer inborn attributes of Man. Like the animal that will soon go by a different name, Man derived from forgetfulness and random noise, the background of all media". KITTLER, op. cit., p. 210. 
[...] deixam de ser agentes da escrita para se tornarem superfície de inscriçáo").22 Nietzsche é o McLuhan do século XIX: é o primeiro a transformar em filosofia a percepçâo, extraída diretamente de sua experiência com um aparato tecnológico, de que escrever nâo se trata mais de uma atividade do humano que se expôe na passividade do meio. "Nossas ferramentas de escrita também trabalham o nosso pensamento" é a realizaçăo quase profética que ecoa, de forma extemporânea, nas primeiras palavras do prefácio de Friedrich Kittler para Gramofone, Filme, Máquina de escrever: "a mídia determina nossa situaçăo" (KITTLER, 1999, p. xxxix). ${ }^{23}$

Do escrito ao descrito. Retomemos o nosso argumento. O gesto, neste primeiro momento definido como "movimento do corpo ou de uma ferramenta anexada ao corpo para o qual năo há uma explicaçăo causal satisfatória", revelasse-nos também uma funçấo dos aparatos/dispositivos, entendidos ao modo estendido de um Agamben. Em última instância, pensar assim o gesto é compreendê-lo, contra intuitivamente, menos como expressâo do humano (a forma pura da representaçâo, presunçăo de inocência que se esconde por detrás do sujeito moderno), e mais como funçâo do inumano - dos dispositivos! No entanto, há uma diferença, queremos crer, entre os instrumentos/ dispositivos que mobilizam Marinho e os instrumentos/dispositivos que constituem a era da reprodutibilidade técnica. Para expor esta diferença, é preciso o recurso à nossa segunda imagem.

\section{0 gesto inumano}

Imagem 2. "O que aconteceu com o Dilazenze no carnaval do ano passado e nesse carnaval nâo pode se repetir. Tem que ter respeito pela cultura de nossa cidade. Mais responsabilidade na hora de montar a programaçăo dos trios elétricos, que nâo podem estar no mesmo horário dos blocos afro. É tăo simples". O texto de protesto foi postado por Marinho Rodrigues em rede social um dia após o desfile do bloco afro Dilazenze, um dos braços do movimento afro-cultural gerido pelo Terreiro Matamba Tombeci Neto, ter sido quase literalmente atropelado pelo trio elétrico da Banda Guig Guetto e pela multidăo que acompanhava o trio.

Era dia 19 de fevereiro. A programaçăo oficial do Folia Ilhéus 2017 previa desfiles de blocos afro e afoxés na Avenida Soares Lopes à tarde e no princípio da noite. Naquele dia, o primeiro a desfilar foi o afoxé Filhos de Ogum, seguido pelo bloco Yorubá, pelos cortejos do Rastafary, do Lion Dhudê e do Zumbiaxé. Chegando à avenida por volta das vinte horas, o bloco Afro Dilazenze encerraria os desfiles do dia. O Balé Afro Dilazenze performava na cena cultural de Ilhéus o tema carnavalesco "Origens do samba no litoral sul da Bahia", com coreografia do Balé Dilazenze. Além da comissăo de frente, alas de baianas e de crianças, foliōes com camisas do bloco e simpatizantes, puxavam o bloco a Banda de percussăo Dilazenze e a voz de Mestre Ney, em carro de som. O bloco afro

\footnotetext{
22 "Writing in Nietzsche is no longer a natural extension of humans who bring forth their voice, soul, individuality through their handwriting. On the contrary: just as in the stanza on the delicate MaIling Hansen, humans change their position-they turn from the agency of writing to become an inscription surface". KITTLER, Friedrich. Grammophon, Film, Typewriter. Traduçáo: e introduçăo: Geoffrey Winthrop-Young e Michael Wutz. Stanford, California: Stanford University Press, 1999, p. 210.

"Media determine our situation". KITTLER, op. cit., p. xxxix.
} 
Dilazenze deveria completar o percurso destinado ao desfile com uma apresentaçáo diante do Comissăo de Avaliaçáo do Folia Ilhéus 2017, alojada em camarote armado ao lado da Igreja Matriz de Săo Sebastiăo.

Aconteceu que o trio elétrico da Banda Guig Guetto, comandado pelo vocalista Falcăo, vinha no encalço do bloco Dilazenze desde o começo da Avenida Soares Lopes e, nas imediaçóes da curva que disporia lado a lado o bloco e o trio elétrico, separados apenas pela faixa que delimitava as duas pistas da avenida, repetiu-se um confronto já costumeiro nos carnavais da Bahia: "Peraê, peraê, peraê, peraê, peraê! Colé, meu irmáo? Segura essa aí". ${ }^{24}$ À semelhança da letra da música de Gerônimo, transcrita por Marinho na sequência da postagem de protesto feita nas redes sociais, o encontro-confronto-dueto que se seguiu entre o vocalista Falcăo e o Mestre Ney, ambos acompanhados por gestos, gritos de ordem e movimentos dos corpos dos foliôes que seguiam, misturadamente, o bloco afro e o trio elétrico, dá a ver uma dura incompatibilidade de modos de existência:

E o cara do trio lá de cima olha: / "Legal massa! / Pessoal do bloco afro é uma beleza estar aqui com vocês, / Vamos levar o som" / E o negăo lá de baixo falando. / "-Qual é, meu irmăo? / É nenhuma, rapaz! / Aqui é boca de zero nove! E é o suingue da gente! / Vá, pegue seu caminhăo e siga seu caminho, / Que a gente vai seguindo o nosso, meu irmăo!". 25

A conversa que se seguiu entre o vocalista Falcăo e o Mestre Ney ressoou na avenida Soares Lopes. A potência técnica do som do trio elétrico continuava a levar os foliôes a avançarem para dentro das fronteiras espaciais do bloco. Corpos e mais corpos seguiam desfazendo a composiçáo das alas: o som do trio sobrepondo-se ao som da banda de percussâo, fiscais da comissăo oficial da organizaçấo do carnaval de Ilhéus e integrantes do bloco, aqueles responsáveis pela linha humana de demarcaçáo

24 Transcriçăo da letra da música Macuxi, muita onda/Eu sou Negăo (Gerônimo): Imenoami, imenoami / Imenoami, imenoami / Orei ma, orei ma / É ikei, ikei / Muita onda / Ê ikei, ikei / É macuxi, muita onda / E aí chegaram os negros / Com toda a sua beleza / Com toda a sua cultura / Com toda a sua tradiçâo / Com toda sua religiăo / E tentada, motivada / A ser mutilada / Pelos heróis anônimos da história / Estamos aqui e eles sobreviveram / E no bum bum bum bum bum bum / bum bum bum bum bum bum / No seu tambor / O seu negăo vai tocando assim / Pega a rua Chile / Desce a ladeira / Tá na praça Castro Alves / Ou praça da Sé / Fazendo seu deboche / Transando o corpo / Fazendo o seu fricote / E o negáo assume o microfone / E na beirada da multidăo em cima do caminhăo ele fala / “- Alô rapaziada do bloco / Esse é o nosso bloco afro / Vamos curtir agora / O nosso som / A nossa levada / Que é a nossa cultura / E segura comigo!" / Eu sou negâo / Eu sou negâo / Meu coraçâo é a liberdade / É a liberdade / Eu sou negăo / Eu sou negâo / Meu coraçấo é a liberdade / É a liberdade / Sou do Curuzu, Ilê / Sou do Curuzu, Ilê / Igualdade na cor, essa é a minha verdadé / Igualdade na cor, essa é a nossa verdade / Eu sou negăo / Eu sou negăo / Meu coraçâo é a liberdade / É a liberdade / Eu sou negâo / Eu sou negáo / Meu coraçấo é a liberdade / É a liberdade / E de repente, aparece ao longe / Um carro todo iluminado, é um trio elétrico! / "-Que é isso, meu irmâo? Venha devagar! / Calma! Que é isso, meu rei? Peraê, peraê, peraê, peraê, peraê! / Colé, meu irmăo? Segura essa aí". / E o cara do trio lá de cima olha: / "Legal massa! / Pessoal do bloco afro é uma beleza estar aqui com vocês, / Vamos levar o som" / E o negâo lá de baixo falando. / "-Qual é, meu irmáo? / É nenhuma, rapaz! / Aqui é boca de zero nove! E é o suingue da gente! / Vá, pegue seu caminhăo e siga seu caminho, / Que a gente vai seguindo o nosso, meu irmăo!" / E na levada! / Eu sou negăo / Eu sou negăo / Meu coraçâo é a liberdade / É a liberdade. / Sou do Curuzu, Ilê / Sou do Curuzu, Ilê / Igualdade na cor, essa é a minha verdade / Igualdade na cor, essa é a nossa verdade / Eu sou negâo / Eu sou negâo / Imenoami, imenoami / Imenoami, imenoami / Orei ma, orei ma / Ê ikei, ikei / Muita onda / Ê ikei, ikei / É macuxi, muita onda / Imenoami /Ară, hey! Eu sou negăo / Macuxi, muita onda 
de espaço de ocupaçăo da avenida, gesticulavam nervosos tentando fazer parar o trio, porquanto o vocalista continuava a proferir, eletrizado, um discurso aparentemente inclusivo - "(...) ah, trinta anos de bloco, puxa, que bacana, eu tenho vinte e dois anos, imagina isso? (...) vem, cá, sobe aqui, vamos puxar uma música juntos? (...)". Mestre Ney subiu no trio elétrico chamado por Falcăo; e isso fez parar (colocou temporariamente em suspensăo) o confronto de corpos na avenida Soares Lopes. Aos poucos, a multidâo se retraía e um espaço aberto, mínimo, permitiu ao bloco Dilazenze fazer sua coreografia e seguir caminho, no trajeto demarcado pela organizaçâo do Folia Ilhéus 2017.

Ressalto 3. O que significa a expulsăo do Dilazenze das ruas durante o carnaval em Ilhéus? O que significa que um carro de som e seus foliōes nâo só demandem a retirada - mas de fato quase passem por cima - de um desfile tradicional de uma comunidade da regiâo? Produzir uma resposta depende, antes de mais nada, de que - embora seja nosso horizonte de partida - a singularidade da imagem que por ora elegemos seja, ela mesma, superada: pois que a esta imagem, retratada também na letra da música de Gerônimo (que data da década de 1980!),26 nâo corresponde um gesto isolado, singular. A imagem, seja porque, por um lado, "é a reificaçâo e a anulaçăo de um gesto", seja porque, por outro, "conserva-lhe intacta a dynamis", remete sempre "para além de si mesma, para um todo do qual faz parte" - remete sempre, portanto, a um gesto.27 Ora, e se o gesto, como quer Agamben, também for a "exibiçāo de uma medialidade, o tornar visível um meio como tal",28 o que, portanto, essa imagem - este gesto - significa?

Do escrito ao descrito 2. A nossa hipótese de trabalho: a expulsăo do Dilazenze permite ver/torna visível o gesto de um dispositivo - o gesto inumano. Pensar no gesto do dispositivo, no entanto, requer avançar naquele horizonte que se abre no século XIX: isso

26 Para uma abordagem rigorosa sobre o lugar que esta música ocupa na história das estéticas negras (no chamado movimento afro-cultural) na Bahia Cf.: SILVA, Ana Claudia Cruz da. 0 devir negro: uma etnografia de encontros e movimentos afroculturais. Rio de Janeiro: Papeis Selvagens, 2016.

27 De fato, toda imagem é animada por uma polaridade antinômica: de um lado, ela é a reificaçăo e a anulaçăo de um gesto (é a imago como máscara de cera do morto ou como símbolo), do outro, ela conserva-lhe intacta a dynamis (como nos instantes de Muybridge ou em qualquer fotografia esportiva). A primeira corresponde à lembrança de que se apodera a memória voluntária, a segunda à imagem que lampeja na epifania da memória involuntária. E, enquanto a primeira vive num mágico isolamento, a segunda envia sempre para além de si mesma, para um todo do qual faz parte. Mesmo a Monalisa, mesmo Las Meninas, podem ser vistas nâo como formas imóveis e eternas, mas como fragmentos de um gesto ou fotogramas de um filme perdido, somente no qual readquiririam o seu verdadeiro sentido. Pois em toda imagem está sempre em açăo uma espécie de ligatio, um poder paralisante que é preciso desencantar, e é como se de toda história da arte se elevasse um mudo chamado para a libertaçăo da imagem no gesto. É aquilo que na Grécia era expresso pelas lendas sobre as estátuas que rompem os entraves que lhe aprisionam e começam a se mover; mas é também a intençăo que a filosofia agrega à ideia, que nâo é, de fato, segundo a interpretaçáo comum, um arquétipo imóvel, mas muito mais uma constelaçāo na qual os fenômenos se compōem num gesto. AGAMBEN, Giorgio. Notas sobre o gesto. Traduçâo: Vinícius Nicastro Honesko. Artefilosofia, Ouro Preto, n. 4, jan. 2008., p. 12.

28 O gesto é a exibiçâo de uma medialidade, o tornar visível um meio como tal. Este faz aparecer o sernum-meio do homem e, deste modo, abre para ele a dimensáo ética. Assim como, num filme pornográfico, uma pessoa é apreendida no ato de cumprir um gesto que é simplesmente um meio dirigido ao fim de procurar dar prazer aos outros (ou a si mesma), pelo único fato de ser fotografada e exibida na sua própria medialidade, é suspensa desta e pode tornar-se, para os espectadores, meio de um novo prazer (que seria de outro modo incompreensível): ou como, na mímica, os gestos dirigidos aos fins mais familiares săo exibidos como tais e, por isso, mantidos suspensos "entre le désir et l'accomplissement, la perpétration et son souvenir", naquilo que Mallarmé chama um milieu pur; assim, no gesto, é a esfera nắo de um fim em si, mas de uma medialidade pura e sem fim que se comunica aos homens. AGAMBEN, op. cit., p. 13. 
porque o gesto do trio elétrico náo faz ver outra coisa que os media como instrumentos (autônomos) de programaçăo.

Ressalto 4. A acepçáo política desses dispositivos torna-se evidente tăo logo recuperamos o vínculo entre estética e política. Nos termos de Rancière, a estética trata-se de um "recorte dos tempos e dos espaços, do visível e do invisível, da palavra e do ruído que define ao mesmo tempo o lugar e o que está em jogo na política como forma da experiência" (RANCIÈRE, 2005, p. 16). Já a política, "ocupa-se do que se vê e do que se pode dizer sobre o que é visto, de quem tem competência para ver e qualidade para dizer, das propriedades do espaço e dos possíveis do tempo" (RANCIĖRE, op. cit., p. 17). A política, assim, depende da estética, pois que se dá como forma da experiência. Essa tal forma da experiência, ao mesmo tempo, năo só se abre como espaço "para" a disputa política, mas trata-se ela própria de espaço "de" disputa política. Nulla politica sine aesthetica: porque políticas sâo as formas de perceber! É claro que, a pensarmos os dispositivos como instrumentos de programaçăo (dos nossos sentidos e, portanto, corpos), entăo devemos admitir que essas formas de perceber se inscrevem como que por fora. Elas săo o resultado da dimensăo material imanente aos processos comunicacionais - sâo, nesse sentido, tecnopolíticas. O que equivale a dizer: năo há ato perceptivo que náo seja também uma fabricaçăo tecnopolítica.

Antes de prosseguirmos, é preciso fazer um esclarecimento. Enxergar tal movimento teórico como estetizaçâo da política, aquilo que, precisamente, Walter Benjamin irá denunciar em seu famoso ensaio "A obra de arte na era de sua reprodutibilidade técnica", é incorrer no erro de quem coloca o problema de ponta-cabeça. E isso porque a estetizaçâo da política nazifascista nâo é mais que um produto da politizaçâo inerente à toda estética, desde que entendamos por estética a constelaçăo teórico/política/institucional resultante dos aparatos tecnológicos (e que, como bem nota Kittler, estâo, nesse sentido, sempre além/aquém da estética - porque a antecipam e, até mesmo, a constituem). ${ }^{29}$ Aliás, é o que dá a entender o próprio Benjamin. Vejamos o que ele tem a dizer sobre a estética da guerra:

A crescente proletarizaçâo dos homens contemporâneos e a crescente massificaçăo sâo dois lados do mesmo processo. O fascismo tenta organizar as massas proletárias recém-surgidas sem alterar as relaçôes de produçâo e propriedade que tais massas tendem a abolir. Ele vê sua salvaçăo no fato de permitir às massas a expressăo de sua natureza, mas certamente năo a dos seus direitos. Deve-se observar aqui, especialmente se pensarmos nas atualidades cinematográficas, cuja significaçăo propagandística năo pode ser superestimada, que a reproduçăo em massa corresponde de perto à reproduçáo das massas. Nos grandes desfiles, nos comícios gigantescos, nos espetáculos esportivos e guerreiros, todos captados pelos aparelhos de filmagem e gravaçấo, a massa vê o seu próprio rosto. Esse processo, cujo alcance é inútil enfatizar, está estreitamente ligado ao desenvolvimento das técnicas de reproduçâo e registro. De modo geral, o aparelho apreende os movimentos de massas mais claramente que o olho humano. Multidōes de milhares de pessoas podem ser

29 KITTLER, Friedrich. Grammophon, Film, Typewriter. Traduçăo: e introduçăo: Geoffrey Winthrop-Young e Michael Wutz. Stanford, California: Stanford University Press, 1999, p. 47. 
captadas mais exatamente numa perspectiva a voo de pássaro. E, ainda que essa perspectiva seja tâo acessível ao olhar quanto à objetiva, a imagem que se oferece ao olhar náo pode ser ampliada, como a que se oferece ao aparelho. Isso significa que os movimentos de massa e em primeira instância a guerra constituem uma forma do comportamento humano especialmente adaptada ao aparelho. As massas têm o direito de exigir a mudança das relaçôes de propriedade; o fascismo permite que elas se exprimam, conservando, ao mesmo tempo, essas relaçôes. Ele desemboca, consequentemente, na estetizaçăo da vida política. A política se deixou impregnar, com d'Annunzio, pela decadência, com Marinetti, pelo futurismo, e com Hitler, pela tradiçăo de Schwabing. Todos os esforços para estetizar a política convergem para um ponto. Esse ponto é a guerra. (BENJAMIN, 1985, p. 196 )

A massa vê o seu próprio rosto, mas năo pelo olho humano, e sim pelo aparelho técnico: "o aparelho apreende os movimentos de massas mais claramente que o olho humano". Prossegue Benjamin: "isso significa que os movimentos de massa e em primeira instância a guerra constituem uma forma do comportamento humano especialmente adaptada ao aparelho". Mas Benjamin, aparentemente, dá mais crédito a d'Annunzio, Marinetti e Hitler do que aos próprios aparatos que ele mesmo identifica como capazes de adaptar formas de comportamento humano. Benjamin falha em perceber que, embora a Segunda Guerra náo seja inconcebível sem o Futurismo, ela é de fato inconcebível sem o rádio e sem a televisăo (como já se apontou, uma figura radiofônica como a de Hitler é tăo inseparável do rádio quanto uma figura telegênica como a de um Kennedy é inseparável da televisăo etc.). ${ }^{30}$ Mas Benjamin năo para por aí. Susan Buck-Morss, em "Aesthetics and Anaesthetics: Walter Benjamin's Artwork Essay Reconsidered", 31 chama a atençăo para a última passagem do ensaio, que reproduzimos a seguir:

"Fiat ars, pereat mundus", diz o fascismo e espera que a guerra proporcione a satisfaçăo artística de uma percepçâo sensível modificada pela técnica, como faz Marinetti. É a forma mais perfeita do art pour l'art. Na época de Homero, a humanidade oferecia-se em espetáculo aos deuses olímpicos; agora, ela se transforma em espetáculo para si mesma. Sua auto-alienaçáo atingiu o ponto que lhe permite viver sua própria destruiçáo como um prazer estético de primeira ordem. Eis a estetizaçăo da política, como a pratica o fascismo. 0 comunismo responde com a politizaçăo da arte. (Idem, Ibidem)

Se o fascismo é a estetizaçâo da política, o comunismo deve ser a politizaçâo da arte. O que define a estetizaçâo da política é a alienaçăo sensorial: o fascismo năo cria essa alienaçăo, mas é um produto dela mesma, e por esse mesmo motivo a alienaçấo sensorial fascista ultrapassa o fascismo como horizonte histórico-político (e chega aos dias de hoje, um elemento nada estranho à vida política brasileira contemporânea). Por outro lado, o comunismo deve ser a politizaçâo da arte. Como lembra Buck-Morss, Benjamin náo parece estar apontando aí para a arte como um veículo de propaganda comunista (o realismo soviético etc.): "ele demanda da arte uma tarefa muito mais

\footnotetext{
$30 \quad$ Id. ibid., pp. 2-3.
}

31 BUCK-MORSS, Susan. Aesthetics and Anaesthetics: Walter Benjamin's artwork essay reconsidered. Autumn, Oct., v. 62, 1992. pp.3-41. 
difícil - isto é, desfazer a alienaçâo dos sentidos corpóreos, restaurar o poder instintual dos sentidos corpóreos humanos para a autopreservaçâo da humanidade, e fazer isso năo evitando as novas tecnologias, mas passando por elas" (BUCK-MORS, 1992, p. 5). ${ }^{32}$

Mas cabe aí, é claro, uma breve correçâo: nâo se passa pelas novas tecnologias impunemente. Na verdade, nâo se passa por tecnologia alguma impunemente. Explicamos: Agamben diz que "o dispositivo é [...] uma máquina que produz subjetivaçôes, e só enquanto tal é uma máquina de governo". No entanto, os dispositivos que se produzem hoje, na atual fase do capitalismo, "nâo agem mais tanto pela produçâo de um sujeito, quanto pelos processos que podemos chamar de dessubjetivaçấo". ${ }^{33} \mathrm{O}$ que se ilustra muito bem, por exemplo, no episódio "Nosedive", da série Blackmirror. No episódio, Lacie Pound (interpretada por Bryce Dallas Howard), vive em um mundo em que as pessoas sâo avaliadas por suas postagens em mídias sociais. As condiçôes socias/possibilidades concretas de vida săo dadas pelas avaliaçóes de outras pessoas que também coabitam a mesma realidade/rede social. Lacie Pound quer subir sua pontuaçáo na rede social (algo em torno de 4.2, em um total de 5) para que possa se candidatar a condiçóes de vida melhores num condomínio exclusivo. Para subir a pontuaçăo, a personagem precisa receber boas avaliaçōes da parte de suas relaçóes sociais. Quando, por uma série de desventuras, Lacie Pound tem sua avaliaçâo nas mídias sociais vertiginosamente rebaixada, ela acaba numa sela de prisăo. Sua descoberta é reveladora: ao se envolver em um bate-boca com outro prisioneiro, sente prazer em finalmente poder dizer tudo aquilo que pensava. 0 episódio nos convida a uma dupla reflexăo. Em primeiro, torna evidente a dessubjetivaçâo operante nos dispositivos tecnológicos contemporâneos: Lacie Pound reproduz nas mídias sociais aquilo que ela julga produzir um aumento em sua pontuaçăo, publicaçóes que parecem, em princípio, ir na contramâo de qualquer coisa que se oculta em sua interioridade/subjetividade (o que ela "verdadeiramente gostaria de fazer"). Em segundo, Lacie Pound, quando presa e capaz afinal de expressar-se "livremente", faz ver o que, aparentemente, foi ocultado por debaixo do dispositivo, algo como uma subjetividade "original". Ora, como bem coloca Agamben, o que se póe a descoberto aqui é

[...] a futilidade daqueles discursos bem-intencionados sobre a tecnologia, que afirmam que o problema dos dispositivos se reduz àquele de seu uso correto. Esses discursos parecem ignorar que, se todo dispositivo corresponde a um determinado processo de subjetivaçăo (ou, neste caso, de dessubjetivaçăo), é de tudo impossível que o sujeito do dispositivo o use "de modo justo". Aqueles que têm discursos similares săo, de resto, a seu tempo, o resultado do dispositivo midiático no qual estǎo capturados. (AGAMBEN, 2005, p. 15)

32 He is demanding of art a task far more difficult - that is, to undo the alienation of the corporeal sensorium, to restore the instinctual power of the human bodily senses for the sake of humanity's selfpreservation, and to do this, not by avoiding the new tchnologies, but by passing through them. BUCKMORSS, op. cit., p. 5.

33 O dispositivo é, na realidade, antes de tudo, uma máquina que produz subjetivaçôes, e só enquanto tal é uma máquina de governo. [...] O que define os dispositivos com os quais temos que lidar na fase atual do capitalismo é que eles náo agem mais tanto pela produçăo de um sujeito, quanto pelos processos que podemos chamar de dessubjetivaçáo. [...] Aquele que se deixa capturar no dispositivo 'telefone celular', qualquer que seja a intensidade do desejo que o impulsionou, năo adquire, por isso, uma nova subjetividade, mas somente um número através do qual pode ser, eventualmente, controlado; o espectador que passa as suas noites diante da televisáo náo recebe mais, em troca da sua dessubjetivaçấo, que a máscara frustrante do zappeur ou a inconclusăo no cálculo de um índice de audiência. AGAMBEN, 2005, p. 15. 
Ou seja: seria inútil para Lacie tentar usar o dispositivo para expressar qualquer coisa como uma interioridade original. $O$ dispositivo só pode expressar aquilo que ele produz. Dado que subjetivaçấo e dessubjetivaçăo constituem processos movimentados pelo dispositivo, tal coisa como uma "subjetividade original" a ser expressada nem mesmo parece possível. O alívio de Lacie Pound, neste sentido, responde antes à constataçáo de quem se julga livre por ter sido forçada para fora de um dispositivo, embora tăo somente para ser capturada por outro (a prisăo). O episódio poderia muito bem terminar com as seguintes palavras de Agamben: "As sociedades contemporâneas se apresentam assim como corpos inertes atravessados por gigantescos processos de dessubjetivaçấo que năo correspondem a nenhuma subjetivaçăo real". ${ }^{44}$ Os dispositivos, na medida em que avançamos na era da reprodutibilidade técnica, deixaram de ser apêndices dos indivíduos, e os indivíduos, por sua vez, passaram a ser apêndices dos dispositivos. O humano torna-se, por fim, um subproduto do dispositivo. "Em um sentido lógico", diz Flusser:

[...] o ser humano é um atributo do dispositivo, uma vez que outra pessoa pode substituí-lo enquanto o trabalho prossegue, ainda que a máquina conserve propriedades humanas em um sentido jurídico. Na relaçăo "homem-máquina", a máquina é a constante e o ser humano a variável, o que em si torna o conceito de "propriedade" problemático: capitalistas, bem como proletários, se tornam propriedade de máquinas, embora de maneiras diferentes. Libertarem-se a si mesmos deve, portanto, significar uma libertaçăo das - e năo por meio das máquinas, e a pergunta "quem deve possuir as máquinas", logo, deve significar "existe alguém ou alguma coisa para além das máquinas?". Isso realmente deveria ter sido compreendido imediatamente após a Revoluçăo Industrial. ${ }^{35}$ (op. cit., p. 16)

\section{[É possível?] combater com imagens}

A esta altura é forçoso admitir que as formas de perceber conformam as regras do jogo político. Na era da reprodutibilidade técnica, no entanto, falsa política é comumente o resultado que produzem. Dispositivos distintos náo só produzem formas de perceber/se comunicar distintas, mas sâo eles mesmos veículos epistêmicos/ ontológicos distintos! Um agogô, por óbvio, produz e dialoga com um mundo distinto do trio elétrico. A alienaçáo dos sentidos corpóreos, a anaisthesis, emerge como um efeito da superestesia promovida pelos media autônomos, frutos que săo da atual fase produtiva do capitalismo: seu trunfo se encontra, precisamente, em năo transparecer em sua acepçăo tecnopolítica, mas somente na acepção política, na presunção de inocência

\footnotetext{
$34 \quad$ AGAMBEN, 2005, p. 7.

35 In a logical sense, the human being is an attribute of the apparatus, for someone else can replace him as the work proceeds, although the machine still retains human properties in a juridical sense. In the 'manmachine' relationship, the machine is the constant and the human being the variable, which in itself renders the concept of 'property' problematic: capitalists as well as proletarians become the property of machines, although in different ways. Freeing themselves should therefore mean a freeing from, and not by means of, machines, and the question "Who should own the machines?" therefore means "Is there anyone or anything beyond machines?" This really should have been understood immediately after the Industrial Revolution. FLUSSER, op. cit., p. 16
} 
de que é possível pensar a política para além da aisthesis, ou seja, das formas de sentir/ perceber/etc. - e, portanto, para além das formas da experiência estabelecidas pelos próprios media.

A politizaçâo da arte de um Benjamin deve ser entendida, nesse sentido, como um chamado à guerrilha à moda de Clausewitz (ainda que traduzido por um Foucault, para quem a política é a continuaçâo da guerra por outros meios) - estratégia do perdedor: exercícios de captura, tentativas de interromper/hackear/sabotar a dinâmica totalizadora/homogeneizadora que nos é imposta pelas formas tecnopolíticas predominantes. Tais formas estariam alinhadas àquilo que Rancière denuncia, em suas Dez teses sobre a política, como falsa política ou política policial: se o dissenso é o processo pelo qual os atores interrompem a ordem natural da dominaçáo (cf. também, a esse respeito, o ensaio 0 Desentendimento), a política policial cuida, justamente, de organizar racionalmente, digerir o dissenso, tornando-o, assim, inócuo (faça greve nos finais de semana etc.).

A politizaçâo da arte deve ser, antes de tudo, criminosa, na medida em que disputa com o status quo, literalmente, a colonizaçâo dos sentidos/corpos - disputa, portanto, com o processo de captura das formas de sentir/perceber que emerge desses mesmos aparatos tecnopolíticos, e que dilui a política no plano do real, da disputa, em política do voto. $\mathrm{O}$ grupo Dilazenze ser atropelado pelo trio elétrico emerge, afinal, como aquilo que é: o movimento da anaisthesis, e que produz, como náo poderia deixar de ser, também a anaisthesis política. Se, como quer Agambem, "a política é a esfera dos puros meios, isto é, absoluta e integral gestualidade dos homens", o que é a aboliçăo de um desses meios, o atropelamento de uma gestualidade? O trio elétrico é a morte da diferença.

Nota do teatro de operaçóes. Como operar, no entanto, com veículos epistêmicos/ ontológicos distintos? $\mathrm{O}$ que esteve (está ainda) em causa aqui, após este extenso percurso de pensamento em torno de duas imagens e suas reverberaçōes estético-políticas, năo terá sido (e năo traz consigo) o óbvio. Duas imagens, quatro ressaltos, inúmeras referências à vida ordinária dos homens: o saber filosófico (Nietzsche, Marx, Kittler, Benjamin, Agamben, Flusser, Rancière, Didi-Huberman etc.), produçóes estéticas contemporâneas (dentre essas, o roteiro de uma série da Netflix e a programaçáo de um carnaval no sul da Bahia), referências à presença de mestres e mestras de tradiçôes orais (populares, indígenas, afro-brasileiras) nas universidade brasileiras, inserçóes/ percepçôes de uma dada célula rítmica ainda tăo desconhecida para nós e à espera de que construamos aparatos/dispositivos que permitam subjetivaçōes e agenciamentos coletivos - modos de combate.

Ao longo deste texto propusemos uma costura viável (ainda que ínvia?) para uma dada experiência (heteróclita, concreta, singular), advindas (a costura e a experiência) de nossos extratos de vida e de política como professores universitários que pensam (por) imagens. Mas, lembra-nos Llansol, entre a Literatura e o Mundo há - sempre e ainda - o ressalto de uma frase. Nesses ressaltos, "[A]í, sim, teríamos um princípio de trabalho, o início de uma interpelaçâo entre estéticas praticadas" (LLANSOL, 2002, p. 47). Fizemos, entâo, neste texto, do ressalto de frases e proposiçōes teóricas nosso método próprio-impróprio de passar do descrito ao escrito. Sabemos que, nesse momento, nenhuma conclusâo será possível - ou aceitável - para nós. 


\section{Referências Bibliográficas}

AGAMBEN, Giorgio. Notas sobre o gesto. Traduçăo: Vinícius Nicastro Honesko. Artefilosofia, Ouro Preto, n. 4, jan. 2008.

O que é um dispositivo. Outra Travessia, Florianópolis, n. 5, 2005.

ARRAES, Marcos Alexandre de Melo Santiago. Tramas do Olhar: americanismo, Guerra Fria e a emergência de um novo regime visual no Brasil entre 1945-1964. 2015. 230f. Tese (Doutorado em História pela Universidade Federal de Santa Catarina), UFSC Florianópolis, 2015.

BENJAMIN, Walter . Magia e Técnica, Arte e Política: ensaios sobre literatura e história da Cultura. Trad. Sérgio Paulo Rouanet. Brasiliense, 1985.

BUCK-MORSS, Susan. Aesthetics and Anaesthetics: Walter Benjamin's artwork essay reconsidered. Autumn, Oct., v. 62, 1992.

DIDI-HUBDERMAN, Georges. Devolver uma imagem. In: ; ALLOA, Emmanuel (Orgs.).

Pensar a Imagem. Belo Horizonte: Autêntica, 2015.

FLUSSER, Vilém. Gestures. Traduçăo: Nancy Ann Roth. Minneapolis/London: University of Minnesota, 2014.

KITTLER, Friedrich. Gramophone, Film, Typewriter. Traduçăo e introduçăo: Geoffrey Winthrop-Young; Michael Wutz. Stanford: Stanford University, 1999.

LLANSOL, Maria Gabriela. O Senhor de Herbais: breves ensaios literários sobre a reproduçâo estética do mundo, e suas tentaçōes. Lisboa: Relógio D água, 2002.

MARX, Karl. Grundrisse: manuscritos econômicos de 1857-1858: esboços da crítica da economia política. Traduçâo: Mario Duayer; Nélio Schneider. Sáo Paulo: Boitempo, 2011.

O Capital: crítica da economia política. Traduçăo: Rubens Enderle. Sâo Paulo: Boitempo, 2013. Livro I: o processo de produçâo do capital.

NIETZSCHE, Friedrich. Genealogia da moral: uma polêmica. Traduçăo, notas e posfácio: Paulo César de Souza. Sáo Paulo: Companhia das Letras, 1998. GM II:3.

RANCIÈRE, Jacques. O Desentendimento - política e filosofia. Traduçăo: Ângela Leite Lopes. Sâo Paulo: 34, 1996.

Ten Theses on Politics. Theory \& Event , v. 5, Issue 3, 2001. Disponível em: https:// muse.jhu.edu/article/32639. Acessado em 11 de novembro de 2017

A partilha do sensível: estética e política. Traduçăo: Mônica Costa Netto. Sâo Paulo: 34, 2005 .

SILVA, Ana Claudia Cruz da. 0 devir negro: uma etnografia de encontros e movimentos afroculturais. Rio de Janeiro: Papeis Selvagens, 2016. 